\title{
Business Strategy Role as Mediation of Management Capability and Orientation of Entrepreneurship on Business Performance (A Study on Micro and Small Scale Seaweed Business in Takalar District, South Sulawesi Province)
}

\author{
Ibrahim Dani \\ Faculty of Economics, Makassar Muslim University of Indonesia \\ E-mail: ibrahim_dani19@yahoo.co.id
}

M. S. Idrus

Faculty of Economics and Business University of Brawijaya Malang

Umar Nimran

Faculty of Economics and Business University of Brawijaya Malang

Achmad Sudiro

Faculty of Economics and Business University of Brawijaya Malang

Received: Nov. 28, 2012

Accepted: December 19, 2012 Published: January 1, 2013

doi:10.5296/jmr.v5i1.2774

URL: http://dx.doi.org/10.5296/jmr.v5i1.2774

\begin{abstract}
This study aims to examine and analyze: (1) whether the business strategy is directly influenced by management ability, entrepreneurship orientation, (2) whether business performance is influenced by management ability, entrepreneurship orientation, both directly and indirectly, through business strategy as mediation. Theoretically, the results of this research is expected to be enrich and complete the repertoire of knowledge in strategic management field, especially micro and small entrepreneurship, so it can be useful for
\end{abstract}




\section{Macrothink}

Journal of Management Research

ISSN 1941-899X

2013, Vol. 5, No. 1

academics, practitioners and government. The population in this study is businessman. Respondents used as sample are 82 people seaweed entrepreneurs at micro and small scale based on Law No. 20 of 2008 in Takalar District South Sulawesi Province. The sampling method is census and an analytical method used in hypothesis testing is Path Analysis. The results of this study indicate that: (1) management capability indirectly affects on business strategy, (2) entrepreneurship orientation directly influences business strategy. (3) management capability directly affects business performance 4) entrepreneurship orientation indirectly affects on business performance but through business strategy as a mediating variable (5) business strategies directly affect the performance of the business. An important finding in this study shows that: the management ability and their respective business strategies directly affect the performance of the business, while management ability and entrepreneurship orientation indirectly affect on business performance but through business strategy.

Keywords: Management capability, Entrepreneurship orientation, Business strategy, Business performance 


\section{Introduction}

South Sulawesi Province as one of the provinces in Indonesia, as well as other province, attempts to increase incomes from various community activities through various efforts, such as encouraging micro and small enterprises from different sectors and one sector is developed the seaweed fisheries sector.

Convenient position of South Sulawesi is both as a gateway in eastern Indonesia and also as transport facilities linking smoothly the city of Makassar as the capital of the province with scattered regencies in South Sulawesi. The development of seaweed cultivation prospect other than supported by convenient location, it also has enough land resources that are still quite spacious. It is fishponds for cultivation of Gracilaria sp. and land for seaweed farming Euchema sp. approximately 59,331 hectares and furthermore, the status of seaweed cultivation in South Sulawesi has now been ousted by the local government as one of the leading commodity in the fisheries sector.

Seaweed in Takalar District is cultivated in two places, namely on pond and at sea. In 2010, for extensive fishponds with an area of 1439 hectares is managed by farmers, with production by 31,797 tons and its production value of IDR 128,006,575,000. Meanwhile, for cultivation in the sea with an area managed by farmers is 10,436 hectares, the production amounted at 417,424 tons, and the production value is IDR 626,136,000,000. It provides an both appeals and opportunity for the businessmen at the level of micro, small, medium and large.

Fishery marketing in the Takalar District is inseparable with the South Sulawesi province, where the South Sulawesi fishery commodities are marketed for export purpose, inter-provincial and local. While micro and small seaweed entrepreneurs in Takalar Districts still market their products on the local markets which are on a large scale and industrial companies in the city of Makassar. While for Makassar city, almost entirely is marketed among the provinces like to Surabaya and Jakarta in the dried seaweed shape. Accordingly, since the seaweed is mostly done by micro and small enterprises, so that Juoro (1995) explains that small and micro businesses can be considered as the basis for the robustness of the industry structure, this is because the items products manufactured by big business is being sub working at SMEs, in addition to the selling price of SMEs products are relatively cheap (Suryana, 2003).

\subsection{Underlying this research}

The task of a manager is fairly complex and multidimensional; it requires a number of skills. Skills required to manage a department or an organization can be summarized in three (3) categories: conceptual, human, and technical (Daft, 2002). While Alessandri (2008) proves that the risk influence goes beyond the decision process, thus rationalizing the decision-making process affects the output decision (Nooraie, 2008). In line with Ramo (2009), it is proved that the emotional and social skills impact on productivity.

Therefore, management skills significantly affects on the risk and product development (Surachman, 2007). In the same way, the organizational innovation and organizational learning, both together promote entrepreneurship to improve the competitiveness (Garcia, 
2006). Positive management capabilities have significant impact on the performance of small and medium enterprises (Suci, 2009). The findings also show that, if an entrepreneur has good management skill, it will improve their business performance. Along with Latif (2002), he proves that if an entrepreneur has good management skills, it will improve their business performance.

Amit and Schumaker (1993) prove that the management capabilities significantly influence business performance. Furthermore, Daft (2002) proves that management ability has no effect on the development of technology, in addition globalization and innovation that is the part of the business strategy in order to improve business performance. Some characteristics of the entrepreneur described by Idrus (1999), greatly affect the success of the business performance running. These characteristics are self confidence, task result oriented, risk taker in the form of time, money, health, and spirit, having leadership attitude, having authenticity (originality), being future oriented (future oriented). The success of the business is determined how many features are embedded in the entrepreneur's soul.

There are some researches on entrepreneurial orientation such as Zahra et al. (2000) proves that a positive relationship between entrepreneurial orientation, profitability and growth. Similar with Zahra and Covin (1995), they prove that the existence of a positive relationship and significant influence. Suci (2009) has also proved that entrepreneurial orientation has positive and significant impact on business strategy and business performance in small and medium enterprises. Therefore to determine whether there is influence of entrepreneurship orientation to business strategy and business performance, Lee and Tsang (2001) prove that to know the entrepreneurship orientation, it can be used indicators below:

(1) Be not satisfied yet when the objective has not been obtained yet (Need for Achievement),

(2) Keep trying though others say it is impossible (Need for Achievement),

(3) Continue to work until it reaches the desired goal (Need for Achievement),

(4) What has been achieved is a result of hard work (Internal Locus of Control),

(5) Gain profit or loss determined by self-effort (Internal Locus of Control),

(6) Be able to control myself (Internal Locus of Control),

(7) Believe that many others can work as well as me (Self Reliance),

(8) Be avid to make their own decisions (Self Reliance),

(9) Prefer to involve friends (Self Reliance),

(10)Like to meet new people (Extroversion),

(11) Take the initiative to start a conversation (Extroversion),

(12)Prefer to be with densities (Extroversion). 
Many experts emphasize the role of entrepreneurship in small and medium enterprises. For small and medium enterprises, there are a lot of things studied related to business strategy, strategic entrepreneurship and innovation (Hitt et al., 2001). While the SME business strategy, regarding to the suitability of internal capabilities and activities of the company with the external environment in which companies must compete using strategic decisions and usually use the following strategies: new products on the previous market, the product in a particular market niche, being into specific segments and making changes on product characteristics (Suryana, 2003).

Generally, small and medium entrepreneurs rely on many strategies that are based on the spirit of entrepreneurship (Hankinson et al., 2000). Meanwhile, according to Suwarsono (2008), he explains that the intensities and formalities strategies on SME are quite simple and partial. Through the steps, a company tries to achieve strategic competitiveness and profits above the average; therefore there are two main models to be achieved (Hitt et al., 2001):

(1) Industrial organization model, shows that the external environment is a major determinant, when the company involves into a particular industry cost leadership or differentiation strategy, (2) Resource-based model, which assumes that each company is a resources unity and unique, the company uses its resources and capabilities that are valuable, rare, inimitable and cannot be replaced (core competencies). Furthermore, according to McCarthy (2003), strategy can be interpreted as directions based on organizational scale and decision on the products, the market scale and competitiveness elements improvement. Some scholars have conducted research related to multicomplex, futurity, industry expertise, synergy of different decision (integration), as well as adaptiveness (Miller and Freisen, 1988) and innovation related to technology, marketing, production, new products, proactiveness and risk taking.

Miles and Snow (1998) explain that companies can implement Complex Product Innovation (innovation challenges) strategy to achieve success and marketing differentiation (differentiation products marketed) as well as strategy in anticipating changing and environmental stability. The effectiveness of all types of business strategy depend on substantial the operational activities that vary widely. It is then to be integrated into forms/ patterns that define the company's business strategy and competitive position in the industry, Gray (1999) notices that the business strategies of small and medium enterprises have 2 (two) scales, namely:

(1) Proactive, which is a strategy that continues to see opportunities ahead and tend to promote the initiative. (2) Reactive, that strategy that tends to be careful in making an approach (by waiting and seeing). Furthermore, some types of small business strategy need to be done.

Furthermore, Supriyono RA (1990), explains that the selection of a busimess strategy is the process of decision making to choose among holding strategic alternatives being considered and will be used and implemented to achieve its goals in excellent way. In SMEs, the decision lies in the selection of top management strategy as well as the owner. Factors to be consider in choosing a strategy are: managerial perceptions of the external dependence, managerial attitudes toward risk, managerial awareness of the company's future strategies in 
the past, the relationship of managerial and organizational structure, and the effect of lower levels of management in strategy selection.

The strategy selection is limited by the company's dependence on outside parties in order to survive and achieve prosperity, such as: owner, competitor, customer, supplier, government and society. In addition, it is also influenced by the relative change of market sectors, types of challenges faced, resources availability opportunities, and changing condition faced by small businesses. The product life cycle is also important as one of 11 other important variables that determine the selection of the strategy. Therefore, related to the business strategy with the performance of small firms, Miller and Friesen (1988) prove that in using dimension to the strategy is to:

Futurity of decision, integration decision, while time makes the analysis with: industry expertise, multiplicity of decisions, product market innovation, proactiveness and risk-taking. Several previous studies try to compare the pure strategy or the strategies that have been combined or modified (hybrid strategy) on the performance of both the companies and the industry. Kumar et al. (1997) proves that the focus cost leadership strategy produces the best performance in the hospital industry. Focus cost leadership strategy is a combination of low cost strategies (overall cost leadership) and focus strategy taken from Porter's Generic strategies, which is overall cost leadership, differentiation and focus which are called pure business strategy, whilst a combination or coalition is called Hybrid Strategy. Suci (2009) proves that the business strategy has significant and negative effect on the performance of small businesses.

It is based on the observation and study of the results of data analysis found that it can be seen that the business strategy applied to the small and medium enterprises is low cost and differentiation strategies together are known as Hybrid Strategy or strategies combined. Furthermore, Philips (2000) proves that business strategy affects the performance of the business, contrary to Miller (1987) and Hopkins (1997) who prove that the business strategy has insignificant relationship and quite different to business performance.

\subsection{The Research Problem}

1) whether the management ability influences on the business strategy of the micro and small scale seaweed business in Takalar District, South Sulawesi, 2) whether the entrepreneurial orientation influences on business strategy of the micro and small scale seaweed business in Takalar District, South Sulawesi, 3) whether management capabilities influences performance of micro and small scale seaweed business in Takalar District, South Sulawesi, 4) whether the entrepreneurial orientation influences performance of the micro and small scale seaweed business in Takalar District, South Sulawesi, 5) whether business strategy influences business performance of the micro and small scale seaweed business in Takalar District, South Sulawesi.

\subsection{Purpose of This Study}

1) to review and analyze the influence of management capabilities on business strategy of the micro and small scale seaweed business in Takalar District, South Sulawesi, 2) to review 


\section{Macrothink Institute ${ }^{\mathrm{TM}}$}

and analyze the influence of entrepreneurial orientation on business strategy of the micro and small scale seaweed business in Takalar District, South Sulawesi, 3) to review and analyze the influence of management capabilities on performance of the micro and small scale seaweed business in Takalar District, South Sulawesi, 4) to review and analyze the influence of entrepreneurial orientation on performance of the micro and small scale seaweed business in Takalar District, South Sulawesi, 5) to review and analyze the influence of business strategies on the performance of the micro and small scale seaweed business in Takalar District, South Sulawesi.

\section{Conceptual Framework and Research Hypotheses}

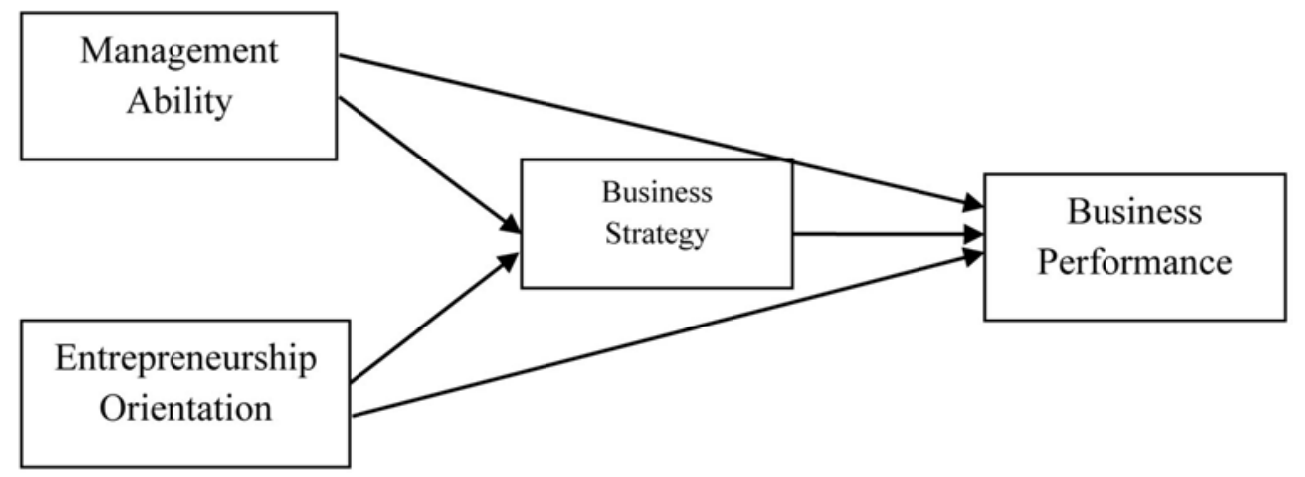

Description:

H1: Daft et al. (2002), Surachman (2007), Nooraie (2008) and Suci (2009).

H2: Zahra and Covin (1995), Idrus (1999) and McCarthy (2003).

H3: Mintzberg (1979), Robins and Coulter (2005) and Suci (2009).

H4: Covin and Selvin (1991), Becherer and Maurer (1999) and Stewad et al. (2003).

H5: Hansen and Mowen (2000), Sugiarto (2006), Moko (2008) and Suci (2009).

\section{Research Hypothesis}

H1: The management ability significantly influences the business strategy of micro and small scale seaweed business in Takalar District, South Sulawesi.

H2: The entrepreneurship orientation significantly influences the business strategy of micro and small scale seaweed business in Takalar District, South Sulawesi.

H3: The management ability significantly influences the performance of micro and small scale seaweed business in Takalar District, South Sulawesi.

H4: The entrepreneurship orientation significantly influences the performance of micro and small scale seaweed business in Takalar District, South Sulawesi. 


\section{Macrothink}

H5: The business strategy significantly influences the performance of micro and small scale seaweed business in Takalar District, South Sulawesi.

\subsection{Operational Definition of Variables}

The independent variables in this study are the ability of management, entrepreneurship orientation and business strategy, while the dependent variable is business performance. For the management ability on the strategy, theories and previous researches are done by Daft (2002), Latif (2002), Surachman (2007), Alessandri (2008), Nooraie (2008), Ramo (2009), Suci (2009). While for the entrepreneurship orientation on the business strategy, theories and previous researches are done by Zahra and Covin (1995), Idrus (1999), McCarthy (2003), Suci (2009).

For the management ability on the business performance, theories and previous researches are done by Mintzberg (1979), Robins and Coulter (2005), Suci (2009). Meanwhile, for the entrepreneurship orientation on the business performance, theories and previous researches are done by Covin and Selvin (1991), Becherer and Maurer (1997), Stewad et al. (2003), Zahra et al. (2000), Suci (2009).

For the business strategy on the business performance, theories and previous researches are done by Miller and Friesen (1984), Miles and Snow (1988), Covin and Slavin (1991), Gray (1999), Becherer and Maurer (1999), Hansen and Mowen (2000), Lee and Tsang, (2001), Philips (2004), Sugiarto (2006), Suwarsono (2008), Moko (2008), and Suci (2009).

\section{Methods}

The approach used in this study is a quantitative approach. This study also adds some explanatory information from some respondents to complete the results obtained from the quantitative approach. This research is a census research, where the entire population is selected for the study. The population is small and micro entrepreneurs amounted at 82 respondents in details: 24 people of micro and 58 people of small entrepreneurs which are included as criteria in Law No.20 in 2008.

In the design of the questionnaire set, it uses some indicators that reflect latent variables and items and also open-ended questions with a Likert scale, the validity and reliability tests are also performed. To test the proposed model, the statistical techniques used is Path Analysis (Solimun, 2011)

\section{Results}

\subsection{Hypothesis Testing}

By using path analysis with confirmatory factor analysis (CFA) program AMOS 18.0 (Analysis of Moment Structure, Arbukle, 1999).

\subsection{Criteria Evaluation for Goodness-of-Fit}

Evaluation of the accuracy of the model has essentially done at the time the model is estimated by AMOS (Ferdinand 2006, Ghozali 2011). A complete evaluation of this model can be done as follows: 


\subsection{Evaluation of the Normality Assumption Fulfilled Up Data}

Univariate and multivariate normality of the data are used in this analysis; tested by using AMOS 18 about the assessment of normality. By referring to the value in column CR, it can be concluded that all the variables use normal distribution.

\subsection{Evaluation of Multicollinearity and Singularity}

By using Amos 18 software, the evaluation of Multicollinearity and Singularity can be detected by looking at the determinant value of the sample covariance matrix. It indicates that the determinant value of the sample covariance matrix is 0.003 . It is concluded that there is no multicollinearity or singularity, thus the data is fit to use.

\subsection{Measurement Results of Every Construct or Latent Variables}

Weight Factor (Factor loading) And Average (mean) of Indicator Variables

\begin{tabular}{|c|c|c|c|c|}
\hline Variables & Indicators & $\begin{array}{l}\text { Indicator } \\
\text { Codes }\end{array}$ & $\begin{array}{l}\text { Loading } \\
\text { Factors }\end{array}$ & Mean \\
\hline \multirow[t]{8}{*}{$\begin{array}{l}\text { X1. Management } \\
\text { Ability }\end{array}$} & $\begin{array}{l}\text { 1. Being able to communicate with the } \\
\text { employees. }\end{array}$ & $(\mathrm{X} 1.1)$ & 0,756 & 4,07 \\
\hline & 2. Being able to work on time. & (X1.2) & 0,723 & 4,26 \\
\hline & 3. Being able to make decision. & (X1.3) & 0,780 & 4,23 \\
\hline & 4. Being able to delegate job. & (X1.4) & 0,739 & 4,06 \\
\hline & 5. Being able to make business plan. & (X1.5) & 0,660 & 3,51 \\
\hline & 6. Paying attention on environment change. & (X1.6) & 0,483 & 3,59 \\
\hline & 7. Being able to build reliable teamwork. & (X1.7) & 0,481 & 3,72 \\
\hline & 8. Being able to finish conflicts. & (X1.8) & 0,398 & 4,04 \\
\hline \multirow[t]{8}{*}{$\begin{array}{l}\text { X2.Entrepreneur- } \\
\text { ship Orientation }\end{array}$} & $\begin{array}{l}\text { 1. Being unsatisfied before achieving goals. } \\
\text { 2. Keeping on trying when the others say it is }\end{array}$ & $(\mathrm{X} 2.1)$ & 0,786 & 4,11 \\
\hline & impossible. & $(\mathrm{X} 2.2)$ & 0,800 & 4,17 \\
\hline & 3. Gaining the result of hard work. & (X2.3) & 0,902 & 4,12 \\
\hline & 4. Gaining profit or loss on self-depending. & (X2.4) & 0,731 & 4,23 \\
\hline & 5. Being able to so self-control. & (X2.5) & 0,477 & 4,18 \\
\hline & $\begin{array}{l}\text { 6. Believing that many people are able to work } \\
\text { as well as I can. }\end{array}$ & $(\mathrm{X} 2.6)$ & 0,555 & 4,04 \\
\hline & 7. Preferring to involve the employees. & (X2.7) & 0,611 & 4,04 \\
\hline & 8. Building communication with the customers. & $(\mathrm{X} 2.8)$ & 0,625 & 4,09 \\
\hline \multirow[t]{6}{*}{$\begin{array}{l}\text { Y1. Business } \\
\text { Strategy }\end{array}$} & $\begin{array}{l}\text { 1. Strategy made recently, influence future } \\
\text { activities. }\end{array}$ & (Y1.1) & 0,795 & 4,07 \\
\hline & $\begin{array}{l}\text { 2. Right decision by combining all interests } \\
\text { available. }\end{array}$ & $(\mathrm{Y} 1.2)$ & 0,709 & 3,82 \\
\hline & $\begin{array}{l}\text { 3. Fast reaction in solving problems occurred. } \\
\text { 4. Beneficial environment in introducing the }\end{array}$ & (Y1.3) & 0,763 & 4,05 \\
\hline & business by innovating. & (Y1.4) & 0,620 & 4,00 \\
\hline & 5. Periodically, contacting the customers. & (Y1.5) & 0,783 & 4,11 \\
\hline & 6. The leader is courageous in risk-taking. & (Y1.6) & 0,694 & 4,07 \\
\hline Y2. Business & 1. Sales growth & (Y2.1) & 0,618 & 4,07 \\
\hline \multirow[t]{3}{*}{ Performance } & 2. Profit growth & (Y2.2) & 0,720 & 3,93 \\
\hline & 3. Assets growth & (Y2.3) & 0,998 & 4,15 \\
\hline & 4. Workforces increase & (Y2.4) & 0,347 & 3,51 \\
\hline
\end{tabular}




\section{Macrothink}

\subsection{Model Conformance Testing Results}

Analysis of the model fit to the model fit criteria such as Goodness of Fit Index (GFI), the adjusted GFI (AGFI), Tucker Lewis Index (TLI), Comparative of Fit Index (CFI), and Root Mean Square Error of Approximation (RMSEA) for the individual model and complete model. The results of testing the model conformance (goodness of fit indices) shows that the overall evaluation of the constructs done is above the critical values so do test the conformance of further model.

Based on empirical models proposed in this study to test the hypothesis, the results obtained are as follows:

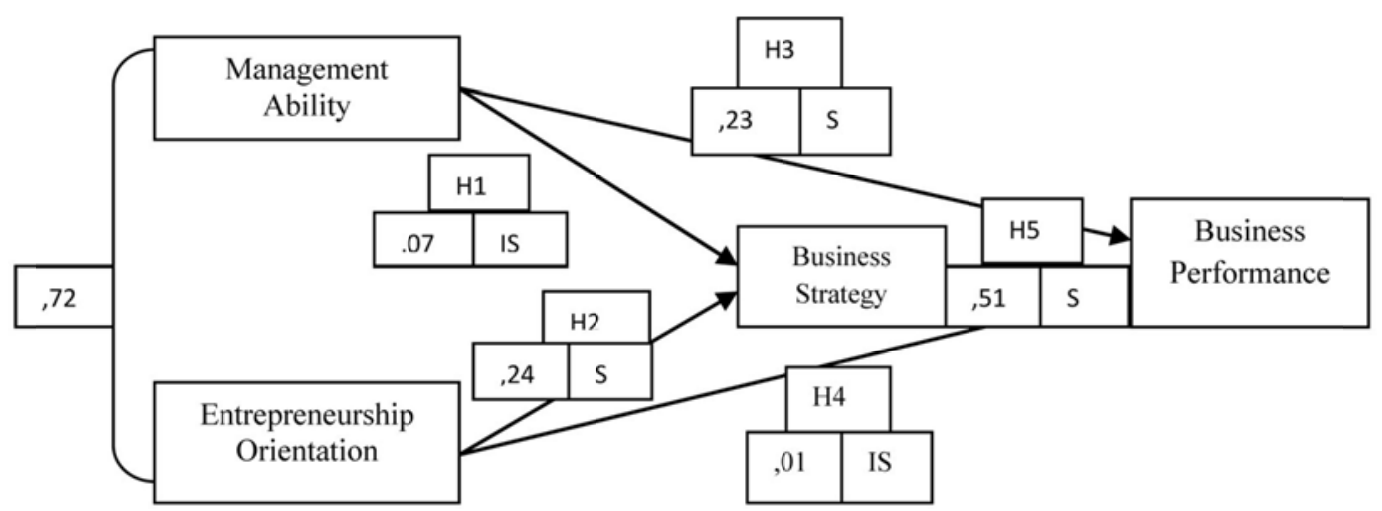

Explanation: S: Significant

IS: Insignificant

Hypothesis Testing

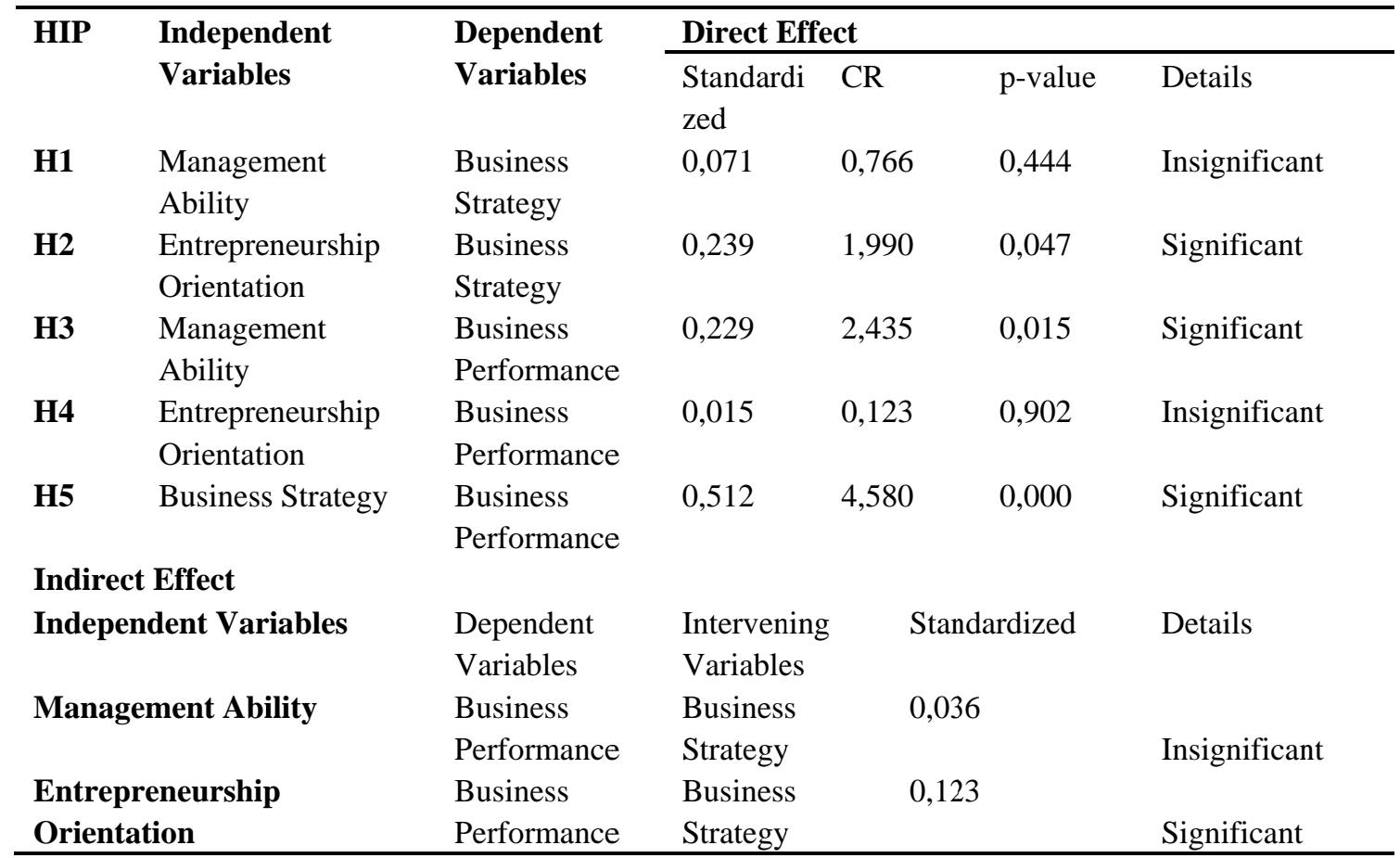




\section{Hypothesis Testing Results:}

Hypothesis 1, it is proved that the management ability does not support strategy business or influence indirectly.

Hypothesis 2, it is proved that the entrepreneurship orientation supports the business strategy or influence directly.

Hypothesis 3, it is proved that the management ability increases business performance or influence directly.

Hypothesis 4, it is proved that the entrepreneurship orientation does not support the performance business or influence indirectly on the business performance but the through business strategy

Hypothesis 5, it is proved that the business strategy supports business performance or influence directly.

Based on the principle tryming theory, the final models are recommended:

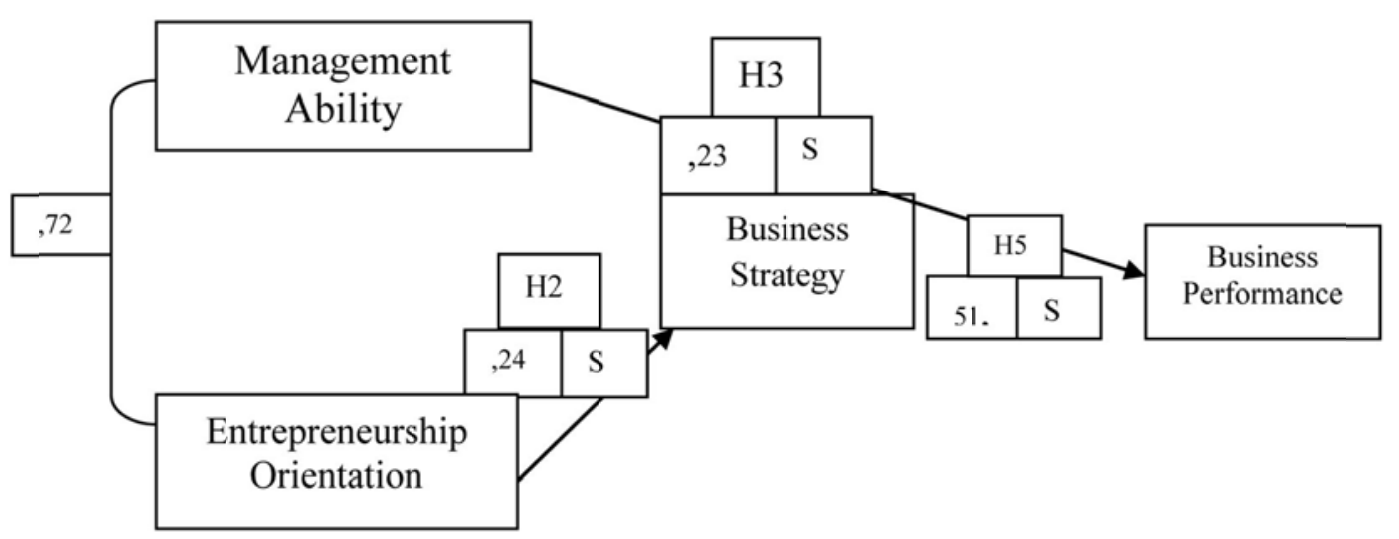

\section{Discussion}

The management ability owned by entrepreneurs does not support the business strategy. Or the management ability influence indirectly on the business strategy. These findings contradict the results of previous studies, according Alessandri (2008), Nooraie (2008), Ramo (2009), Garcia (2006) Surachman (2007) prove that the management skill influences significantly on product risk and development.

The entrepreneurship orientation owned by entrepreneurs supports the business strategy. Or the entrepreneurship orientation directly influences the development of the business strategy. This finding is consistent with results of previous studies, conducted by McCarthy (2003), Idrus (1999), Zahra and Covin (1995), Suci (2009) which prove that entrepreneurship orientation has positive and significant impact on business strategy and business performance of small and medium enterprises. 


\section{Macrothink}

The management ability owned entrepreneurs improves their business performance. Or the management ability directly affects the business performance. These findings are consistent with previous studies by Robbins and Coulter (2005), Suci (2009) that prove if the management ability has positive and significant impact on business performance.

The entrepreneurship orientation can improve the business performance, when implementing the appropriate business strategy. The entrepreneurship orientation indirectly affects on business performance but through the business strategy. These findings contradict the results of the studies by McCarthy (2003), Covin and Selvin (1991), Idrus (1999), Steward et al. (2003), Vitale, Giglierano and Miles (2003), Smart and Conant (1984), Suci (2009) proving that entrepreneurship orientation has positive and significant impact on business strategy and business performance of small and medium enterprises.

The business strategy can improve the business performance. Or business strategy directly affects the performance of the business. This finding is consistent with results of previous studies, as the study conducted by Moko (2008), Philips (2004), Covin and Slavin (1989), Miller and H. Friesen (1982) proving that operating performance improves if you have competitive advantages.

\section{Conclusions and Recommendations}

\subsection{Conclusion}

1. The management ability possessed by an entrepreneur does not support the business strategy. Or the management ability indirectly affects the business strategy.

2. The entrepreneurship orientation owned by an entrepreneur is proved supporting the business strategy. The entrepreneurship orientation directly influences the development of business strategy.

3. The management capabilities possessed by an entrepreneur is proven to improve the business performance. Or the management ability directly affects the business performance.

4. The entrepreneurship orientation is proven to improve the business performance, when applying business strategy appropriate. The entrepreneurship orientation indirectly affects on the business performance but through the business strategy.

5. The business strategy is proved to improve the business performance. Or the business strategies implemented by entrepreneurs directly affects the business performance.

\subsection{Suggestion}

1. An entrepreneur in managing micro and small scale seaweed business are better paying attention on management ability and entrepreneurship oriented, other than that they should implement business strategy in improving business performances.

2. Management ability possessed by an entrepreneur can be benefited in implementing business strategy, so the punctuality in work and being attentive to customers and suppliers will improve its business performance. 
3. For the next researches, it can be completed the management strategies variables with other variables include the management strategy so that research results will be comprehensive

4. Similar research can be conducted and developed beyond Takalar District or South Sulawesi Province, to get a comprehensive picture, as well as over other fishery products or commodities outside the fisheries sector

5. It still needs to be explored the indicators that have not been used in this research, since not all of the indicators of respective variables is being used.

\section{References}

Amit, R., \& Schoemaker, P.J. H. (1993). Strategic Assets And Organizational Rent, Strategic Management Journal, 14(3), 33-46. http://dx.doi.org/10.1002/smj.4250140105

Allessandri, Todd M. (2008). Risk and Procedural rationality, A Behavioral Theory Perspectve, Journal Of Strategy and management, 1(2),196-217.

Arbuckle,J.L., \& Wothke, W. (1999). Amos 18.0 Users Guide: SPSS, Small Waters Corporation.

Becherer, C. Richard, \& Maurer G. John. (1999). The Poractive Personality Disposition And Entrepreneurial Behavior Among Small Company Presidents. Journal Of Small Business Management, 37(1), 28-36.

Central Bureau of Statistics. (2011). Takalar in Figures. Makassar. p.1-38.

Central Bureau of Statistics. (2011). Export Commodities Analysis. Jakarta. H. 34.

Bureau of Agricultural Commodity Exports Statistik. (2011). Perkembangan. Jakarta.h. 2-23.

Covin, J. G., \& Slevin, D.P. (1991). Strategic Management of Small Firms in Hostile And Begin Environment. Strategic Management Journal Jan/Feb, 10(1).

Daft, R.L. (2002). Organization Theory And Design, 5th Ed. West Publishing Company, St. Paul, MN.

Department of Marine and Fisheries South Sulawesi Province. (2011). Makassar. h1-90

Ferdinand, Augusty. (2006). Management Research Methods, Second Edition, Publisher Board Diponegoro University, Semarang

Gray, Judi. H. (1999). Empirical Model Of Small Business Success Working Paper 18/99, April, Monash Univ., Faculty Of Business And Economics: 1-13.

Garcia, Victor.J. (2006). Antecedent And Consiquences Of organizational innovation And Organizational Learning in Enterpreneurshif, Journal management \& Data Systems, 106(1), 21-42.

Ghozali, Imam. (2011). Structural Equation Models Concepts And Applications With AMOS 19.0 program, Publisher: Board Publisher Diponegoro University in Semarang. 
Hopkins, \& Hopkins. (1997). Strategic Planning-Financial Performance Relationship In Bank, A Causal Exemination, Strategic Management Journal, 18(8), 635-652. http://dx.doi.org/10.1002/(SICI)1097-0266(199709)18:8<635::AID-SMJ904>3.0.CO;2-\#

Hankinson, Alan, David Bartlett, \& Bertrand Ducheneaut. (2000). The key Factors In The Small Profiles Of Small - Medium Enterprise Owner- Managers That Influence Business Performance. International Journal Of Entrepreneurial Behavior And Research, 3(4).

Hitt, Michael, A.R. Duane Ireland, \& Robert E. Hoskisson. (2001). Strategic Management: Competitive And Globalization. Fourth Edition South-Western Publishing.,USA.

Idrus M.S. (1999). Entrepreneurship Development Strategy (Entrepreneurship) and The Role of Higher Education in the Context of Building a Competitive Advantage (Advantage compatitive) Bangsa Indonesia In Melinium Third Inauguration Speech Title Professor in Management Sciences, 6 March 1999, UB, Malang.

Juoro, Umar. (1995). Global Competition and Economic Indonesia Decade 1990 - An 8-year Prisma XIX

Kumar, K, Subramanian R., \& Younger C. (1997). Pure versus Hybrid Performance Implications Of Poter's Generic Strategies. Health Care Management Review Fall, 47-60. http://dx.doi.org/10.1097/00004010-199710000-00008

Latif, Dafiz A. (2002). Model For Teaching The Management Skills Component Of Managerial Effectiveness To Pharmacy Student. Review, 377.

Lee, D. Y., \& Tsang, E. W. K. (2001). The Effect of Entrepreneurial Personality, Background And Network Activities on Venture Growth. Journal of Management Studies, 38(4), 583-602.

Lawrence, R. Jauch, \& William F. Glueck. (1998). Strategic Management and Business Policy. (terjemahan Erlangga).

Mintzberg, H. (1990). Managing For growth. New York: Wiley.

Miles, R. E., \& Snow, C. C. (1988). Organizational Strategy, Structure, and Process. New York: McGraw-Hill.

Miller, D., \& Friesen, P. (1988). Archetypes of Strategy Formulation Management Science, 24, 253-280.

McCarthy, B. (2003). The Impact of The Entrepreneur Personality on The Strategy Format And Planning Process In SMES’s. Journal of Management, 154-172.

Miller, Danny. (1987). The Structural and Environmental Correlates of Business Strategi. Strategic Management Journal, 8.

Moko, Wahdiyat. (2008). Implementation of Strategies to Improve the Competitiveness of SMEs Merchants Food and Drink In Malang, Journal of Management Application, 6(1), 131-138 


\section{Macrothink}

Journal of Management Research ISSN 1941-899X 2013, Vol. 5, No. 1

Nooraie, Mahmood. (2008). Decision Magnitude of Impact Decision and Strategic Decision Magnitude of Impact and Strategic Decision Marking Process Output. Journal Management Decision, 46(4), 640-655.

Philips, P. A. (2000). The Statrategic Planning/Finance Interface: Does Sophistication Really Matter?. Management Decision, 38(8), 541-549. http://dx.doi.org/10.1108/00251740010378273

Ramo, laura. Guillen. (2009). The Impact Of Social And Emotional Competencies On Effectiveness Of Spanish Executives. Journal Of Management Development, 28(9), 771-793.

Robbins, Stephen P., \& Mary Coulter. (2005). Management. Sevent Edition, New Jersey: Prentice Hall Inc.

Smart, D. T., \& Conant, J. S. (1994). Entrepreneurial Orientation, Distinctive Marketing Competencies And Organisational Performance. Journal Of Applied Business Research, 10(3), 28-38.

Solimun. (2011). Structural Equation Modeling (SEM) Lisrel Dan Amos, First published Malang: State University of Malang.

Stewart, Jr W. H., Carland, J. C., Carland J. W., Watson W. E., \& Sweo R. (2003). Entrepreneurial Dispositions and Goal Orientations: A Compative Exploration Of United States And Russian Entrepreneurs. Journal Of Small Business Management, 41(1), 27-46. http://dx.doi.org/10.1111/1540-627X.00065

Supriyono R. A. (1990). Corporate Strategy and Policy Management. Second Edition, Publisher BPFE, jogyakarta.

Suryana. (2003). Entrepreneurship Practical Guide, Tips And Process to Success. Salemba Four, Revised Edition.

Sugiarto. (2006). Corvorate Good Governance, Companies Can Improve Performance. School of Economics IBII Jakarta, 6(1), 34-46.

Suwarsono, Muhammad. (2008). Strategic Management. 4th Edition, Publisher School of Economics YKPN Jogyakarta.

Surachman. (2007). Influence Skill Management And Business Orientation Against Acceptance Rate Risk And Its Impact On Small Industries Product Development In Java Tinmur. Journal of Management Application.

Saints, Rahayu Praise. (2009). Entrepreneurial Orientation, Dynamic Capabilities and the Management And Its Impact on Performance. Application Management Journal, 7(2).

Vitale . R, Giglierano J., \& Miles. M. (2003). Entrepreneurial Orientation, Market Orientation, And Performance In Established And Start-Up Firms, http://www.uic.edu/cba/ies/2003papers. 
Zahra, S., \& Covin, J. G. (1995). Contextual Influences On The Corporate Entrepreneurship Entrepreneurship-Performance Relationship: A Longitudinal Analysis. Journal Of Business Venturing, 10, 43-58. http://dx.doi.org/10.1016/0883-9026(94)00004-E

Zahra, S. A, Ireland, R. D. Gutierrez, \& Hitt, M.A. (2000). Privatization And Entrepreneurial Transformation. Emerging Issues And A Future Research Agenda. Academy Of Management Review, 25(3), 509-524. 